\title{
Corrosive Control: State-Corporate and Gendered Harm in Bordered Britain
}

\author{
Victoria Canning ${ }^{1}$
}

Published online: 25 May 2020

(c) The Author(s) 2020

\begin{abstract}
As gendered discourses around migration proliferate, research and practitioner focus is often trained on experiences of women in interpersonal capacities, primarily in regard to subjections to predominately male violence. Drawing on research in Britain and activist participation with women seeking asylum, this article expands this focus into the realm of state-corporate harms against women. Previous research demonstrates that immigration law and policy often work to minimalize autonomy at the ground level, and dependence on spousal visas or housing and finances can exacerbate dependence on men, including violent men. This article argues that this punitive landscape of Britain's asylum system facilitates further violence against women seeking asylum, rather than ensuring protection. Moreover, harm is inflicted by the structures of coercive control set forth by the state and its amorphous relations with corporations. Such structures are largely manufactured by the British state, but increasingly enacted by its corporate allies. These environments, I argue, mirror those of domestically violent perpetrators and work to gradually corrode women's autonomy and indeed sense of safety.
\end{abstract}

"For the people who need our help and protection the most, let Britain be a beacon of hope."

Former Prime Minister Theresa May, October 6, 2015 (previously British Home Secretary, 2010-2016)

"Everyone's terrified, terrified of the Home Office. The Home Office is like a tyrant... so many people describe it as, it's like torture."

Interviewee, asylum rights campaign coordinator in the North West England, February 2017

Victoria Canning

victoria.canning@bristol.ac.uk

1 School for Policy Studies, University of Bristol, 8 Priory Road, Bristol BS8 1UQ, UK 


\section{Introduction: Confronting an Intersectional Continuum of Violence}

Legal and social discourses around migration and refugee status have gradually evolved to take greater account of the rights of women seeking asylum (Canning 2010, 2014, 2016, 2017; Crawley 2001; Girma et al. 2014; McKinnon 2016; Pickering 2010). Concerted efforts have been made to recognize the gendered differences in trajectories of violence and abuse that women and girls disproportionately face, specifically sexual and domestic violence. In more recent parliamentary and media campaigns in Britain, this has expanded to include sexual trafficking, domestic or ritualistic religious abuses (or so-called "honor" violence) and the threat or impacts of female genital mutilation.

At the surface level, the British state has been one such advocate of the eradication of this violence. For example, unlike many other European countries, the Home Office adopted a strategy to review asylum applications from a gender-sensitive perspective, implementing Gender Issues in the Asylum Claim guidelines (first introduced in 2010 and updated 2018). Likewise, sexual trafficking has gained increased public and parliamentary condemnation with escalated efforts to control what has been termed a marker of "modern day slavery"1 (for a full discussion, see Gadd and Broad 2018). With this in mind, it would serve to reason that the lives of women seeking asylum in the United Kingdom (UK) - in my research, Britain (England, Scotland, Wales), specifically—should thus have improved in correlation with such recognitions. ${ }^{2}$

This article argues that the reality is to the contrary. As the landscape of immigration law and practice has become increasingly punitive (Aas and Bosworth 2013; Aliverti 2012; Bosworth and Turnbull 2015), including to those seeking sanctuary, the everyday lives of many women seeking asylum are transformed into an extension of control, degradation and, in some cases, violence. This article, however, goes further still in harvesting empirical examples of instances where women's safety or wellbeing - or both-can be compromised or diminished through actions and decisions made by the British state. It draws comparisons between the abusive behaviors attributed to domestic violence and maps them onto experiences reported in empirical research. Overall, it highlights the increasingly amorphous relationship between states and corporations (Snider et al. 2003; Tombs 2016) in their roles related to border controls, and problematizes the multifarious ways that coercive - and corrosive - controls can be enacted in the lives of women seeking asylum.

\section{Establishing a Framework on "Corrosive Control"}

Before outlining the empirical arguments that underpin this article, I first solidify a conceptual framework for identifying, naming and addressing corrosive control. In the context of gendered border harms, this combines two primary perspectives-intersectionality (Crenshaw 1989; Grzanka 2014) and state-corporate harms and crime (Davis 2003; Kramer and

\footnotetext{
1 One clear example is the implementation of the "National Referral Mechanism" in July 2015, which is purportedly a "framework for identifying victims of human trafficking or modern slavery and ensuring they receive the appropriate support" (National Crime Agency 2015).

2 Note that the terms "Britain" and the "United Kingdom" (or "UK") are included in this article. The research area did not include Northern Ireland, but I refer to the UK when discussing aspects of border controls and asylum which affect Northern Ireland.
} 
Micholowski 2002; Lasslett 2010; Tombs 2016)—alongside definitions of coercive control, corrosion and domestic violence.

The daily controls that those subjected to domestic violence experience (coercive control, sexual abuse and marital rape, or even the specter of violence yet to come) are well-documented, but are often simultaneously invisible. All of these regulate and demean women. According to Women's Aid (2015), domestic abuse can include, but is not limited to, the following:

- Coercive control (a pattern of intimidation, degradation, isolation and control with the use or threat of physical or sexual violence)

- Psychological and/or emotional abuse

- Physical abuse

- Sexual abuse

- Financial abuse

- Harassment

- $\quad$ Stalking $^{3}$

Importantly, in 2015, the British government moved toward strengthening controls around coercion with the introduction of Section 76 in the Serious Crime Act 2015. This amendment focuses explicitly on "intimate or family relationships" and is a significant step in addressing violence within the domestic sphere, including parental abuse by children. As the Crown Prosecution Service (2017) points out, the British government's definition outlines the following:

Coercive behavior is an act or a pattern of acts of assault, threats, humiliation and intimidation or other abuse that is used to harm, punish, or frighten their victim; Controlling behavior is a range of acts designed to make a person subordinate and/or dependent by isolating them from sources of support, exploiting their resources and capacities for personal gain, depriving them of the means needed for independence, resistance and escape and regulating their everyday behavior.

There are clear and understandable reasons why this legislation has focused on domestic and intimate relationships (Walby and Towers 2018), not least because ten women per month are still killed in the UK, where a male partner or former partner is the sole or primary suspect in causing her death (Ingala-Smith 2016). Yet, and as the crux of this article emphasizes, many of the behaviors identified above are ironically embedded or enacted in the lives of people seeking asylum. As will be evidenced throughout, this happens at both a structural level and through micro-level aggressions, in both the public sphere and in the home.

In this article, I employ the dual concepts of state-corporate harm and intersectional feminism to establish what I refer to as corrosive control. The Oxford English Dictionary (2019) defines "corrosion" as "the process of corroding or being corroded," while the Cambridge English Dictionary (2019) defines "corrosive" as "harmful and causing bad feeling." In the context of gendered border harms and for the purpose of this article,

\footnotetext{
${ }^{3}$ I use the definition offered by Women's Aid because it more accurately reflects the state-corporate nexus this article seeks to address in the lives of women's seeking asylum. Women's Aid is "a grassroots federation working together to provide life-saving services and build a future where domestic violence is not tolerated" (https://www.womensaid.org.uk/about-us/who-we-are/).
} 
state-corporate harm and crime relate more to state facilitated abuses than solely state initiated abuses (Kramer et al. 2002). That is, states develop harmful structures to contain and control migrant bodies, but corporations increasingly enact the policing, control and confinement of these bodies. This pattern is not new and is echoed increasingly across continents (Boochani 2018; Weber and Pickering 2011). Building on work by Kramer and colleagues (2002), Lasslett (2010) underscores that many harms are inflicted outside of criminogenic actions, hence the emphasis here on state-corporate harms, as well as crimes (see also Canning 2017).

Drawing on intersectional feminism, I identify the intersectional experiences of structural state-corporate harms in the context of corrosive control. As Asylum Aid (2011) has asserted, "asylum is not gender neutral." This is not to say that men do not experience harms in seeking asylum-far from it. Precarious work, exploitation and disproportionate confinement in prisons and immigration detention centers provide evidence otherwise (Bhatia 2015; Burnett and Whyte 2010). What this does mean - and what this article demonstrates - is that women disproportionately experience intersectional oppressions which have very specific consequences. While this relates to the trajectory of potential abuses in a single woman's life-or, indeed, continuums of violence across women as a social demographic (Kelly 1988) - it can still overlook the microcosms of harm which are themselves extensions of patriarchal controls (Cassidy et al. 2018).

As this article shows, corrosive control is the banal, everyday stripping of autonomy and humanity that occurs throughout the process of seeking asylum in the UK, entrenched in coercive interactions in an increasingly restrictive and controlling landscape. Coercive controls are grinding, but ordinary, and often enabled or initiated directly by states and their corporate allies. The impacts are gendered, intersectional and-for survivors of domestic or sexual violence - can extend or compound a continuum of violence in the lives of migrant women.

\section{Methodology}

The broad arguments drawn out here stem from multiple projects over a ten-year period. Primary empirical data included in this article are based on interviews across three periods: reflections from a decade of activist participation and ethnography with women seeking asylum in the North West England (2008-present) (see O'Reilly 2011); ${ }^{4}$ interviews with general practitioners, medical doctors, psychologists, sexual violence counselors, and social workers, including a two-year ongoing project funded by the Economic and Social Research Council (ESRC) (2008-2011; 2016-2017); and oral histories with women seeking asylum. Overall, the ESRC project (2016-2018) incorporated seventy-four in-depth semi-structured interviews with border agents, psychologists, support workers, refugee rights activists and other such social actors working with people seeking asylum in Britain, Denmark and Sweden. Twenty of these interviews took place in Britain, supplemented with over 500 hours of ethnographic activist research with women seeking asylum. For the purposes of this article, only data from Britain are included so as to facilitate an in-depth, rigorous case study approach (see Flyvbjerg 2006).

${ }^{4}$ See Canning (2017) for further information on this aspect of work, activism and method. 
Interview responses were coded using NVivo 8 and were analyzed from an interpretive perspective (Mason 2002), read and then deconstructed in relation to the wider literature and the socio-structural and political context in which they occurred. Analysis of parts of a woman's oral history included in this article was more complex. Considering the number of recordings and the depth and volume of data, a linear structure first had to be re-constructed to read the history literally, before applying a dual interpretive analysis from myself and Asma, a woman seeking asylum in North West England. It is important to note, however, that themes were also informed by the longer-term participation with women seeking asylum, through which I was enabled to focus on aspects of the process that can otherwise be invisibilized or determined as a "by-product" of the asylum system.

The correlations between women's stories, interviews and the organizations with which I have worked or volunteered, supplemented with evidence from wider research, such as the reports mentioned above, indicate a more concrete set of themes. These are then drawn out through lived experience of borders as projected through an oral history with Asma that I collated between 2016 and 2018. In all, five long-term, in-depth oral histories were included in the ESRC project across the three countries (see Canning 2019a, b), although this article focuses on only one so as to provide a linear account of the intricacies of internalized and everyday bordering (van Houtum and van Naerssen 2002; Yuval-Davis et al. 2019). This methodological approach does not, by itself, produce an account representative of women's experiences more broadly. When used in conjunction with the multiple method approach taken throughout this research journey, however, oral history facilitates unique insight into the micro-level impacts of macro-level policies, legislation and practice.

\section{The Banality of Harm in Britain's Asylum System}

As with all countries bound to the Convention Relating to the Status of Refugees (also known as the 1951 Refugee Convention") (UNHCR 1951), the UK has a duty to consider applications for asylum based on well-founded fears of persecution as stipulated in the original convention and its 1967 protocols. Like all Northern European countries, the contemporary landscape of asylum in Britain has deviated somewhat from the origins of the convention. Anti-immigration sentiment has perforated political and public discourse (Berry et al. 2015; Burnett 2016), with the gradual escalation of hardened borders that promote illegalization, criminalization and-where possible-deportation, often in place of humanitarianism (Andersson 2014; Hasselberg 2016; McMahon and Sigona 2018; Webber 2012).

What interests me here, however, is the way in which internalized borders in Britain work to reduce autonomy, social participation and overall wellbeing. People seeking asylum receive around $£ 37$ per week from the British state to buy food, clothes and transport. Travel can be limited because a bus ticket accounts for approximately two-thirds of the daily allowance, which (among other social activities) affects women's capacity to engage in domestic or sexual violence services.

For people whose applications for refugee status have been refused, who are submitting appeals, and who do not receive legal aid, this $£ 37$ should cover these fees. The removal of legal aid for cases falling under Article 8 (the right to family life) of the Universal Declaration of Human Rights was facilitated by the Immigration Act 2014-meaning that people who are prohibited from exercising their right to work are responsible for financing their own access to justice. The most recent estimate I have seen for a solicitor to appeal a 
negative decision for such a case was $£ 1600$ - around 44 weeks of saving, if one opts not to eat or travel altogether. While this might seem like an exaggeration, I have been told on numerous occasions by women and men that they pay their legal fees by eating less. When I asked Asma how she planned to pay for her appeal, for example, she responded:

Asma: I don’t get money, but I have $£ 10 \ldots$ or $£ 20$, I want to save, you know. I don't eat everything.

Canning: So if you have to pay solicitors' fees, do you eat less food?

Asma: Yes, of course. I don't buy shopping. Last year I was keeping money, I collect $£ 200$ from my money to save, like I pay my friend, 'Please can you do shopping for me and give me money please, I don't have money' ... But we have sacrifice for ourself, we don't eat, we live hungry and eat less. ${ }^{5}$

Furthermore, housing - one of the most significant issues people face every day-is usually in the poorest areas of the most deprived cities in the UK (Lyons and Duncan 2017). Much of the responsibility for housing provision for people seeking asylum in Britain has shifted from local councils to corporations, which include G4S and Serco. Since December 2012, in the North West England, Serco (2016) has been:

responsible for the provision of accommodation, transport and related support services for asylum seekers in the North West of England and Scotland \& Northern Ireland, being two of the six the COMPASS regions. Serco is currently caring for over 15,000 asylum seekers across these two regions. [emphasis added]

According to Parliament.UK (2016), “[s]ince 2012 accommodation has been provided to asylum seekers via six regional Commercial and Operational Managers Procuring Asylum Support Services contracts, known as COMPASS." The idea that Serco's role falls under the category of "care" is an incredibly contentious one in the UK. The years 2016 and 2017 saw some devastating accusations of mismanagement and unacceptably low standards of accommodation, adding to a body of criticism which has already developed in light of sexual violence allegation against Serco staff in IRC Yarl's Wood-the main immigration detention facility for women (see Bosworth 2016). In my conversations and interviews with women seeking asylum, xenophobia and Islamophobia is commonplace (Canning 2017; see also Burnett 2016). Housing conditions range from acceptable to dire, with heating problems, rodent and vermin infestation (e.g., cockroaches, rats, slugs), and chronic dampness and/or mold. Likewise, the threat of unlimited detention in one of the UK's eight Immigration Removal Centers (IRCs) is often at the forefront of people's consciousness when they are required to sign at the Home Office. ${ }^{6}$ Considering that the UK detained 27,300 people in such centers in 2017 alone (Silverman and Griffiths 2018), this is an understandable concern.

\footnotetext{
5 Asma receives Section 4 support, which is basic support for "failed asylum seekers" at the end of a claim, but who have not or cannot return to their country of origin. At the time of interview, this meant that her funds were paid through an Azure card. This offered access to buying limited goods at one of six stores, but no cash. Therefore, paying for legal aid was not possible, so she swapped her card funds for cash with friends.

${ }^{6}$ People seeking asylum are required to register on a regular basis with the Home Office. This may be weekly, bimonthly or, in rarer cases, less or more frequently than that.
} 
What emerges is a state with responsibilities to provide protection, but which does so in a way that limits other aspects of social engagement, removing autonomy over daily decisions and facilitating unnecessary and often degrading struggles. As argued elsewhere (Canning 2016, 2017), these not only have the capacity to negatively affect wellbeing broadly but, through the added pressures of temporal uncertainty, restrict any sense of security and thus can compound the impacts of previous experiences of trauma.

\section{A Case of "The Domestic Controller": When Protection Meets Subjection}

For Asma, domestic life had been complex prior to moving to the UK. As a child, she felt restricted by societal norms (which she acknowledges have now shifted in areas) but, at the time, meant she was dependent on male members of her family:

They don't allow. My brothers and my father, they were very strict. They don't allow girls to go easily like outside with friends or even friends' homes.

Her marriage, an arrangement between her husband and her brother, was controlling and physically violent:

he was beating me like that, you know the 7-Up Coke bottles, he throw them too much, beat me too much. Even he broke my phone as well, my computer, and even my clocks, he was ... they were very bad people, you know, even his mum, very bad, and they kill my ... another sister-in-law, his big brother's wife, they killed her.

Because Asma's sister-in-law and a close friend had been killed by family members, she decided that a move with her husband to the UK would facilitate her leaving him in a way that would not be possible in her country of origin:

he was beating me a lot, he broke ... he was punch me, he ... this, my bone is broken [points to cheek, which has not fully healed].

I had a husband who was beating me too much, and it was violence and my sister said, 'They are not good, why are you living there?' I said, 'I want to leave him but I can't leave in [says name of country] 'cause they don't let women leave here.'

Having given one of the two names she uses to refer to herself, Asma was deemed unreliable and her claim was refused after a period of three years. She was detained in Yarl's Wood IRC, became homeless upon release, lived in a church for five years, and has since developed complex illnesses including arthritis, depression, diabetes, and recurring headaches from physical abuse. After leaving her abusive husband, who accepted voluntary return to his country of origin, she gave birth to their first child. At the time of writing, Asma has spent more than ten years of her life in the British asylum system.

For Asma, domestic violence spanned across trajectories similar to those defined by Women's Aid, including instilling fear:

Asma: he [her husband] was teasing me, he was beating me as well. He beat me and he broke my this bone, so now it's painful for me, and the pain is spreading all my head as well. I'm very, very ... I went to the doctor, he gave me ... it's infection inside and he gave me.

Canning: It got infected as well?

Asma: Because it's broken inside. If you see, if you touch there -

Canning: Have they been able to do anything? 
Asma: He would be punch me like that and my eyes was like black.

Cannin: Did he punch you often?

Aasma: Yeah, he was beat me, he broke my clothes, he throw my phone in the wall. He destroy all the things like eggs, bread, everything put on the floor.

Cannin: Was he like that regularly?

Asma: $\quad$ No, any time, when he angry, when he got angry. Like very aggressive man. I was scared from him.

Like Asma, many of the women claiming asylum with whom I have spoken in Britain, Denmark or Sweden have experienced some form of domestic violence, which forms part of the asylum claim. As my research in this area expanded, however, one stark correlation emerged gradually from my data: similar patterns of control, regulation and threat are particularly pronounced in the lives of women taking part in the research or who are involved in campaigns in which I participate. Such abuse continues, in part, because of dependence-financial support, emotional and familial ties, personal relations, love and the loss of a known future. The other side of dependence, however, is fear-the threat of imminent or long-term violence, and the anxiety of what might happen were one to end such a partnership (Ingala-Smith 2016; Kelly et al. 2014).

\section{Instilling Fear as a Mechanism for Control}

The politics of claiming asylum in Britain is deeply entrenched in dependence. From the moment of application, people are positioned to entrust the Home Office with their safety from persecution and depend upon their interviewer to "believe" their story and thus facilitate the granting of protection. Applicants are forced to depend on welfare (because they are not entitled to work), on housing (unless they can provide their own or can depend on other people for accommodation), and, through the policy of dispersal, on the Home Office to decide where they will even live-and then, further, on the agreement of local councils who are part of the dispersal scheme.

The architecture of asylum in Britain also relies heavily on compliance, including opening up interpersonal experiences to scrutiny in the main (or substantive) interview, and weekly or monthly signings at the Home Office. These interactions cause many people immense amounts of anxiety or panic, as Asma highlights and as I have outlined elsewhere (Canning et al. 2017: 47-50). The key reasons for this are the fear of being detained or deported, and the heftiness of the potential outcomes of such interactions:

I was very scared when I go to Home Office because they can detain with children as well. Oh yeah, I feel very, very scared.

As one mental health worker specializing in support for Black and minority communities also explained:

I've seen people... You know how nervous we get when we go for a job interview? When you look at it this is something that their whole life depends on. If they are unsuccessful they could be sent back. I've seen men crying, women absolutely totally being — for weeks.

A social worker-herself a refugee-held similar views: 
This whole process can make you depressed. Some of them walk in fear, live in fear, you don't know where your case is, you don't know what's happening to your case. Always in fear and that affects you, doesn't it, has an impact on your mental health.

The language of fear, expressed in asylum cases, maps onto the kind of "unknowing" or uncertainty, which is prevalent in domestic abuse cases, because "it is the everydayness of living with unpredictability which saps women's energy, depletes their sense of self and isolates them from others" (Stark 2007, in Kelly et al. 2014: 7). This aspect relates particularly to the fear of transcending boundaries set by the controller (e.g., the male partner/ spouse). Speaking about the Danish context, Whyte (2011: 18) argues this form of surveillance functions as "a different kind of power to that of Foucault's panoptic model, one that relies more on uncertainty that on accurately knowing or disciplining its subjects" (emphasis added).

Although the UK has stringent forms of surveillance which are more formalized in some senses, Whyte's observations about uncertainty remain relevant. An individual may never be detained or deported, and yet the specter of these two potential realities often manifests more acutely as the meetings or interactions draw closer. As the Women's Refugee Commission (2016) points out, the constant feeling of uncertainty is compounded by increasingly restrictive asylum policies that facilitate removal or detention more easily and quickly (see Webber 2016). As such—and referring back to the mental health worker's comments above - anxiety is a central aspect of inducing compliance to avoid being "sent back" or detained.

From the outset, then, the power relations between the person seeking protection and certain sectors of the state potentially providing it are not only uneven but exude aspects of coercive power and control. Such forced dependency stands in contrast to the concepts of freedom or civil liberties. Moreover, as I argue below, combinations of abusive behavior-as defined by Women's Aid—are evident within the actions of the Home Office, some Home Office contractors, and private companies working on behalf of the Home Office to implement immigration controls.

\section{The Myth of Safety at "Home"}

As feminist scholars and activists have long argued, the home can represent a paradoxical site of safety and oppression for women, and survivors of domestic violence, more broadly (Stanko 1990). The pervasive notion of the public sphere as risky or unsafe for women can exacerbate an avoidance of perceptively risky spaces outside of the home (Fitzgibbon and Walklate 2017; Stanko 1990; Westmarland 2015). Although such fears can be logical extensions of the social construction of violence against women, it is predominately within the home that women experience coercive, physical, or sexual violence (Ingala-Smith 2016; Kelly et al. 2014). The home thus sits at an uncomfortable nexus between the perceived likelihood of harm or violence, and the statistical ${ }^{7}$ reality of it.

There are three dimensions to this paradox. First, some women in domestically violent circumstances remain dependent on their relationship with their spouse under spousal visas. Indeed, such women may fear the fracturing of a family unit or face the potential of

\footnotetext{
7 I emphasize statistical here so as not to undermine the individual experiences of violence that many women do encounter in public, which are of equal significance in understanding and challenging male violence against women.
} 
leaving a violent partner on which her claim relies, and thus face the threat of deportation (Cassidy et al. 2018; Crawley 2001; Safety 4 Sisters 2016). Second, a fear of Islamophobic, racist and xenophobic violence can encourage self-confinement in the home for women who have experienced verbal or physical abuses. Considering the increase in such violence, particularly since the exacerbation of anti-immigrant sentiment preceding the UK's European Union Referendum (Burnett 2016), this is not an illogical concern. As one women's support worker in Scotland put it:

These dark, gray winter nights, if you don't have access to cash, you're on section 4 or if you are expected to be living in real poverty, even if you are on asylum support, you often have to walk throughout parts of [names city in Scotland] that I wouldn't feel comfortable walking around, let alone if you're a woman in a hijab or a woman of African origin in a very white neighborhood. ${ }^{8}$

This context can thus leave women restricted to the domestic sphere in which other forms of oppression manifest, as we will soon see. Two examples stand out as illustrations. First, when in December 2015 a local organization held a fundraiser, almost none of the organization's members with whom I work made an appearance. When I inquired why they had not attended, the women told me they simply would not leave their house after dark which, in British winter, can be $4 \mathrm{pm}$. On another occasion, I arrived at a Darfuri Community Group ${ }^{9}$ meeting to discuss women's access to support in the aftermath of violence. I was the only woman, with seventeen well-meaning Darfuri men. When I asked where the women were, one man joked that they were too busy with housework to attend.

The third element to this "safety" paradox is that women who are subjected to domestic violence face exclusionary obstacles from support to leave abusive partners, and thus confinement stretches back to their current domestic sphere. Cuts to women's services, particularly under the guise of austerity measures since the economic recession of 2008/2009, have had lethal impacts for women leaving violent partners. For women of color, this has resulted in racialized exclusions from mainstream services (Emejulu and Bassel 2017). For migrant women, specifically those who are undocumented or whose asylum claims have been refused, this has been compounded by the reluctance of domestic refuges to accept women who have no recourse to public funds. As Sisters Uncut (2016) point out, in 2014 alone, 389 women fleeing domestic violence with "no recourse to public funds" were turned away from refuge spaces. As one asylum social worker summarized, "Even if they are victims of domestic violence if they have got no leave to remain, they cannot manage to get to women's refuges because they don't have recourse to public funds."

\section{Corrosive Control: Extending Domestic Controls to Corporate Allies}

There are, however, further issues pertaining to the domestic sphere which stretch beyond the typical perception of the violent perpetrator. As I have discussed elsewhere (Canning 2017), micro-levels of control are endemic in housing, with everything from suggestions on how to use the toilet to how to clean being given in information books provided by

\footnotetext{
${ }^{8}$ From my perspective, this should not be used to suggest that so-called "white working class neighborhoods" are singularly affected by Islamophobia or racism. After all, it is predominantly the upper-middle classes and political elite who define the mediated and legislative environments that promote exclusionary discourses.

9 This was the name of a local group in North West England.
} 
the contracted housing operators. Perhaps more insidiously, some have also used minor wrong-doings, such as leaving fire doors open, with reasons to report tenants (also referred to as "clients") to the Home Office-effectively making minor issues a deportable offense. Asma reflected on such controls, which perforated her feeling of content within her onebedroom apartment. Not only did she have to report any trip away that was longer than seven days to Serco-which indicates the dispersal of social control beyond regular border agents (Cohen 1985) — but she was chastised constantly for any small changes or additions to her apartment. For example, she recalled:

Even when my child was born, after five months I want to go London to see my sister. I was going out and he [the Serco housing manager in charge of her housing block] was coming in. He said, 'Where are you going?' I said, 'I want to see my sister, to go London.' 'You are not allowed to go.'

Asma: He does knock. If I'm no answer he just come inside, but I go and open if I am home. But if no answer, he come.

Canning: And do you ever come back when he has been here while you were out? Asma: $\quad$ I know he's came here, because he just hit my light off.

He gave me so much stress again, he say, 'Why did you put these two kettles?' I said, 'I told you so many times, every time you come to my home, you ask me about this two kettles. I told you, one is working and one is not working. That's why I just boil the water and put another kettle, as a jug. I'm using as a jug. It's not a kettle.

The gendered elements of these controls are no small issue for women dependent on such housing, particularly survivors of domestic violence who are attempting to establish their ownership of space (for a broader discussion of these issues, see Kelly et al. 2014). In one conversation, a woman told me of her humiliation when a male maintenance worker entered her apartment without knocking and before she was able to put on her hijab. In another, a support worker also stated: "There'd be times when I'd be sat in the flat with the women and a couple of guys would just walk in and go into one of their rooms without explanation of what they were doing, and I didn't understand how that was in any way appropriate."

For Asma, this insidiousness also transverses from control to threat of violence or, in Asma's case, racist verbal abuse:

Even my manager is very bad, racist, all the time comment he gave me, he said, 'Why are you people come in this country? You have to go back! Home Office come, soon this house will be empty.'

In another conversation, a young survivor of trafficking told me she could not escape constant phone calls from her housing officer who was upset that she was not present at her accommodation when he regularly visited. The reason was that she had been awarded a short-term fellowship in a local college and, as such, had to attend or lose her place. He resorted to leaving notes in her room, one of which he placed under her pillow-an invasive act which, under any other context, might be deemed stalking.

It is the combination of these elements-coercion, control, forced dependence and reductions in autonomy - which are ultimately corrosive powers. They diminish people's decision-making, personal freedoms, and powers over the mechanisms of everyday life. 
Corrosive controls work to force compliance into the border regime, more broadly, and to extend coercive controls in ways which mirror the actions, intentions and consequences of domestic violence perpetration. For some women, this is again made more complicated by relationships with perpetrators of domestic violence, creating a dualistically structural and interpersonal web of gendered controls which can threaten women's well-being, autonomy, and safety - at the hands of violent partners, as well as at the hands of harmful state-corporate practice, as will now be further discussed.

\section{The Coercive and Corrosive Manipulator}

As mentioned above, it is not legal for people to work while they seek asylum, ${ }^{10}$ and they are dependent on the Home Office and sub-contractors to (a) provide monetary welfare; (b) provide housing in a dispersal area; and (c) ensure protection while in the care of the state. It is key to note that - unless the person applying for asylum has the finances to manage independently - this is not a chosen dependence. Autonomy is almost wholly eradicated for decisions around where to live, what to do, or how to eat. Living in the domestic sphere of asylum accommodation that may be accessed by a third party on short notice-or without any notice at all — can mirror a feeling of invasion. This is similar to what Stanko (1990) referred to as a part of "everyday violence," where autonomy and control belong to others. As one support worker who worked with women living in temporary asylum accommodation put it:

They never seem to feel safe in those hostels, they never seem to feel that they were safe from the Home Office's control, which if you've been through any sort of controlling relationship, an abusive partner ... it just seems that they were just repeating a lot of the characteristics of previous experiences.

Another alternative can be drawn from the lack of adequate housing available in areas that women live, as dispersal to more peripheral or areas unknown to the complainant are used to silence people coming forward with concerns about their housing. As one refugee women's sexual violence counselor suggested:

If you complain about housing... rather than do something or help you within Liverpool, they say, 'OK, you can go to Manchester then.' Had that happen.

This control can extend to relationships with housing officers and maintenance repair. In numerous interviews, as well as in my experience visiting Asma and two other women's homes, patterns emerged suggesting coercive elements of control. That is, women who were relying on home repairs were threatened with being reported to the Home Office if they complained of either non-completion or poor standards of housing or repairs. As a social worker for women seeking asylum argued:

Participant: They are being threatened with their cases, they say, 'I know your case owner and if you say anything...'

Canning: What cause would women have to say anything about the officers?

\footnotetext{
10 With the exception of being granted specific permission. For further information, see UK Visas and Immigration (2014).
} 
Participant: Most of them, the cooker is not working for two months, you have to cook, you can't just be buying microwaveable, and you have kids in the house; the radiators, when it's winter it's so cold, so those are the things, the house is leaking, the toilet is broken, things like that

The outcome is silence: rather than push for acceptable standards of living, people are forced to live in potentially hazardous conditions or without adequate cooking facilities, heating, and lighting (Perraudin 2017). According to one national women's asylum rights campaigner:

women often say that they don't want to complain because they're worried about the impact it can have, they're worried about jeopardizing... you know, what's going to happen in their case and certainly with the housing that's something... It's either they will complain and nothing will be done, it will take a really long time, or they'll just be worried about the impact of complaining.

As Barton and Cooper (2012) show, this issue is indicative of other elements of social housing beyond only the asylum sector. The key disparity here is that complaints or negative interactions with housing officers can result in Home Office intervention, which people fear due to the inherent threat of detention or indeed deportation. This is not an exaggeration; people can be detained on the basis of one or more of thirteen reasons, with the thirteenth being "your unacceptable character, conduct or associations" (asylum detention report, 2014, viewed by author).

For women seeking asylum, sexualized violence can sometimes occur at the hands of those accountable for their safety. In 2013, allegations of contemporary and historic cases of sexual abuse emerged in Yarl's Wood IRC. The Home Office deported four key witnesses, but later two inquiries were commissioned, the Review into the Welfare in Detention of Vulnerable Persons undertaken by former Prisons and Probation Ombudsperson Stephen Shaw, and the Serco-commissioned report Independent Investigation into Concerns about Yarl's Wood Immigration Removal Centre (see Bosworth 2016; Bhatia and Canning 2016 for full discussions). Further reports emerged from research by Women for Refugee Women (W4RW), which found that women detainees were being subject to "knock and walks," where male guards entered their rooms after knocking but not waiting for consent to enter, as well as watching women using showers and the toilet (Girma et al. 2014). As a coordinator for a national refugee women's organization asserted:

Being locked up is incredibly harmful for anyone but in detention, for instance, there are particular experiences that women are disproportionately subject to. So one end of that spectrum is sexual abuse and exploitation in detention but also the kind of intrusions into women's privacy and dignity, women who very often experience forms of gender-based sexual violence in their countries of origin, then they come to the UK and in detention they find themselves being put on suicide watch and being watched by male guards.

While W4RW's most recent report (Lousley and Cope 2017) showed the depletion in this specific form of voyeuristic violence, interviews I have undertaken with practitioners working with women outside of detention raise serious concerns. This includes three occasions where support workers indicated that female clients had been subject to offers of so-called "transactional sex" in their asylum accommodation, where repairs would be 
undertaken in return for sexual "favors." While two interviewees requested not to have the details of their experiences included in this article due to ongoing investigation, one argued that the fear of losing cases prevents women from coming forward with complaints of sexual harassment:

I think other women are more terrified that their case will get ruined and so have been silent and not forward. So I've heard it through another woman who said, 'Yes, I've heard of things like that happening.' But then that's it. We tried to get people to come forward to see if we could do a focus group of it but nobody wanted to speak out.

Considering that unequal power relations facilitate the perpetration of violence in the home, as well as the social silencing of women who may be subject to such exploitative conditions, it should come as no surprise that women may not wish to speak up against either the state or its corporate allies. Thus, there should be rational concern for the wellbeing of women set in this unequal relationship between dependence and safety or wellbeing in their home.

\section{Conclusion: Corrosive Control and the Manipulation of Reality}

As this article has demonstrated, patterns emerge which indicate that the Home Office and corporations working in cooperation hold an immense amount of structural power which transverses the public into the private. On the other hand, the British state still holds obligations of protection toward those in fear of persecution. It is this contradictory disconnect which perhaps most embodies the capricious nature of contemporary Britain's approach to asylum, and which - like many perpetrators of domestic violence-most mirrors the inconstant, changeable and corrosive nature of its internal borders.

Rather than embed humanitarian protection, the structural architecture of the process of seeking asylum in Britain can inflict further harms. While at the surface it embodies the ideals of welfare by providing financial support and housing, at the micro-level, it erodes human autonomy, infantilizes adults, and enforces dependency. Complicity is the foundations of a relationship built on unequal power, and non-adherence to (often unclear) instructions or expectations bears punitive results from an increasingly authoritarian set of actors, state as well as corporate.

As discussed above, domestic violence may be part of many refugee women's histories, but it is not one which is regularly considered a cause for international protection in and of itself. As McKinnon (2016) argues, this is connected to the reluctance to open avenues for increased claims from women with similar experiences. The points raised throughout this article, however, draw concerns beyond the legislative landscape of asylum practice or administrative policy. It provides evidence of the ways in which everyday practicesdecided in the UK Parliament and by Home Office, often enacted by corporate alliesmirror the intentions and actions of perpetrators of domestic violence. Coercive control, a culture of threat and compliance, the potential for repercussions, and the uncertainty of safety in the home-all are reflective of definitions of domestic violence. They are also the key mechanisms of control adopted by the British state (including the Home Office and UK Visas and Immigration) and the corporations and policing bodies working on their behalf. For survivors of domestic violence, such controls contradict the freedoms that had been hoped for in the quest for sanctuary from persecutions elsewhere. 
Acknowledgments This research is funded by the Economic and Social Research Council, grant number ES/NO16718/1. Many thanks to all of the women and practitioners who have offered their time to this research, in particular to Asma. Thanks also to Monish Bhatia, Gemma Lousley and Sarah Turnbull for organizing "Borders, Racisms, and Harms: A Symposium" at Birkbeck University in May 2018 (http:// www.bbk.ac.uk/events/remote_event_view?id=466), and for their comments on earlier drafts of this article.

Open Access This article is licensed under a Creative Commons Attribution 4.0 International License, which permits use, sharing, adaptation, distribution and reproduction in any medium or format, as long as you give appropriate credit to the original author(s) and the source, provide a link to the Creative Commons licence, and indicate if changes were made. The images or other third party material in this article are included in the article's Creative Commons licence, unless indicated otherwise in a credit line to the material. If material is not included in the article's Creative Commons licence and your intended use is not permitted by statutory regulation or exceeds the permitted use, you will need to obtain permission directly from the copyright holder. To view a copy of this licence, visit http://creativecommons.org/licenses/by/4.0/.

\section{References}

Aas, K. F., \& Bosworth, M. (Eds.). (2013). The borders of punishment: Migration, citizenship and social exclusion. Oxford: Oxford University Press.

Aliverti, A. (2012). Making people criminal: The role of the criminal law in immigration enforcement. Theoretical Criminology, 16(4), 417-434.

Andersson, R. (2014). Illegality Inc: Clandestine migration and the business of bordering Europe. Oakland, CA: University of California Press.

Asylum Aid. (2011). Unsustainable: The quality of initial decision making in women's asylum claims. Available at: https://www.refworld.org/docid/4d3435d12.html. Retrieved April 28, 2020.

Barton, A., \& Cooper, V. (2012). Hostels for women and community for women: The 'semi-penal' paradox. In M. Malloch \& G. McIvor (Eds.), Women punishment and social justice: Human rights and penal practices (pp. 136-152). Abingdon, Oxon, UK: Routledge.

Berry, M., Garcia-Blanco, I., \& Moore, K. (2015). Press coverage of the refugee and migrant crisis in the EU: A content analysis of five European Countries. UNHCR Report. Available at: http://www.unhcr .org/56bb369c9.html. Retrieved April 10, 2018.

Bhatia, M. (2015). Turning asylum seekers into 'dangerous criminals': Experiences of the criminal justice system of those seeking sanctuary. International Journal for Crime, Justice and Social Democracy, 4(3), 97-111.

Bhatia, M., \& Canning, V. (2016). Immigration detention: A tale of two reviews. The Institute of Race Relations. Available at: http://www.irr.org.uk/news/immigration-detention-a-tale-of-two-reviews/. Retrieved January 16, 2018.

Boochani, B. (2018). No friend but the mountains: Writing from Manus prison. Translated by O. Tofighian. Sydney, NSW: Picador, Pan MacMillan.

Bosworth, M. (2016). Immigration detention in the UK under review (Again). Border Criminologies. Available at: https://www.law.ox.ac.uk/research-subject-groups/centre-criminology/centreborder-criminolog ies/blog/2016/01/immigration. Retrieved January 16, 2018.

Bosworth, M., \& Turnbull, S. (2015). Immigration detention, punishment and the criminalization of migration. In S. Pickering \& J. Ham (Eds.), The Routledge handbook of crime and international migration (pp. 91-106). Abingdon, Oxon, UK: Routledge.

Burnett, J. (2016). Racial violence and the Brexit State. London: Institute of Race Relations.

Burnett, J., \& Whyte, D. (2010). The wages of fear: Risk, safety and undocumented work. Leeds: PAFRAS.

Cambridge English Dictionary. (2019). Corrosive. Available at: https://dictionary.cambridge.org/dictionary/ english/corrosive. Retrieved July 30, 2019.

Canning, V. (2010). Who's human? Developing sociological understandings of the rights of women raped in conflict. International Journal of Human Rights, 14(6-7), 847-862.

Canning, V. (2014). Violence in Britain: Behind the wire at immigration removal centres. The Conversation. Available at: http://theconversation.com/violence-in-britain-behind-the-wire-at-immigration-removalcentres-25519. Retrieved August 27, 2019.

Canning, V. (2016). Unsilencing sexual torture: Responses to refugees and asylum seekers in Denmark. The British Journal of Criminology, 56(3), 438-456.

Canning, V. (2017). Gendered harm and structural violence in the British Asylum System. Abingdon, Oxon, UK: Routledge. 
Canning, V. (2019a). Reimagining refugee rights: Addressing asylum harms in Britain, Denmark and Sweden. Migration and Mobilities Bristol. Available at: http://www.statewatch.org/news/2019/mar/uk-dkse-reimagining-refugee-rights-asylum-harms-3-19.pdf. Retrieved August 7, 2019.

Canning, V. (2019b). Degradation by design: Women and asylum in Northern Europe. Race and Class, 61(1), 46-64.

Canning, V., Caur, J., Gilley, A., Kebemba, E., Rafique, A., \& Verson, J. (2017). Migrant artists mutual aid: Strategies for survival, recipes for resistance. London: Calverts Publishing.

Cassidy, K., Yuval-Davis, N., \& Wemyss, G. (2018). Intersectional border(ing)s. Political Geography, 66(September), 139-141.

Cohen, S. (1985). Visions of social control. Cambridge: Polity Press.

Crawley, H. (2001). Refugees and gender: Law and process. Bristol: Jordan Publishing Ltd.

Crenshaw, K. (1989). Demarginalizing the intersection of race and sex: A black feminist critique of antidiscrimination doctrine, feminist theory and antiracist politics. University of Chicago Legal Forum, 1989(1), Article 8, pp. 139-167. Available at: http://chicagounbound.uchicago.edu/uclf/vol1989/ iss 1/8. Retrieved July 25, 2019.

Crown Prosecution Service. (2017). Controlling or coercive behaviour in an intimate or family relationship. Available at: https://www.cps.gov.uk/legal-guidance/controlling-or-coercive-behaviour-intimate-orfamily-relationship. Retrieved July 30, 2019.

Davis, A. Y. (2003). Are prisons obsolete? New York: Seven Stories Press.

Emejulu, A., \& Bassel, L. (2017). Women of colour's anti-austerity activism. In V. Cooper \& D. Whyte (Eds.), The violence of austerity (pp. 117-123). London: Pluto Press.

Fitzgibbon, K., \& Walklate, S. (2017). The efficacy of clare's law in domestic violence law reform in England and Wales. Criminology and Criminal Justice, 17(3), 284-300.

Flyvbjerg, B. (2006). Five misunderstandings about case-study research. Qualitative Inquiry, 12(2), 219-245.

Gadd, D., \& Broad, R. (2018). Troubling recognitions in british responses to modern day slavery. The British Journal of Criminology, 58(6), 1440-1461.

Girma, M., Radice, S., Tsangarides, N., \& Walter, N. (2014). Detained: Women asylum seekers locked up in the UK. London: Women for Refugee Women.

Grzanka, P. (2014). Intersectionality: A foundations and frontiers reader. Abingdon, Oxon, UK: Routledge.

Hasselberg, I. (2016). Enduring uncertainty: Deportation, punishment and everyday life. New York: Berghahn Books.

Home Office. (2018). Gender issues in the asylum claim. Available at: https://assets.publishing.service.gov. uk/government/uploads/system/uploads/attachment_data/file/699703/gender-issues-in-the-asylu m-claim-v3.pdf. Retreived March 19, 2019.

Immigration Act 2014. Available at: http://www.legislation.gov.uk/ukpga/2014/22/contents/enacted. Retrieved June 23, 2019.

Immigration Act 2016. Available at: http://www.legislation.gov.uk/ukpga/2016/19/contents/enacted. Retrieved June 23, 2019.

Ingala-Smith, K. (2016). Why does a woman stay with a violent man? Sometimes, to save her life. The Guardian, 7 December. Available at: https://www.theguardian.com/commentisfree/2016/dec/07/femic ide-census-violence-against-women. Retrieved March 19, 2019.

Institute of Race Relations. (2017). Humanitarianism: The unacceptable face of solidarity. London: Institute of Race Relations.

Kelly, L. (1988). Surviving sexual violence. Minneapolis, MN: University of Minnesota Press.

Kelly, L., Sharp, N., \& Klein, R. (2014). Finding the costs of freedom: How women and children rebuild their lives after domestic violence. London: Solace Women's Aid and CWASU.

Kramer, R. C., Michalowski, R. J., \& Kauzlarich, D. (2002). The origins and development of the concept and theory of state-corporate crime. Crime \& Delinquency, 48(2), 263-282.

Lasslett, K. (2010). Scientific method and the crimes of the powerful. Critical Criminology: An International Journal, 18(3), 211-228.

Lousley, G., \& Cope, S. (2017). We are still here: The continued detention of women seeking asylum in Yarl's wood. London: Women for Refugee Women.

Lyons, K., \& Duncan, P. (2017). 'It's a shambles': Data shows most asylum seekers put in poorest parts of Britain. The Guardian, 9 April. Available at: https://www.theguardian.com/world/2017/apr/09/its-ashambles-data-shows-most-asylum-seekers-put-in-poorest-parts-of-britain. Retreived March 19, 2019.

Mason, J. (2002). Qualitative researching. London: Sage.

McKinnon, S. L. (2016). Gendered asylum: Race and violence in U.S, law and politics. Champaign, IL: University of Illinois Press. 
McMahon, S., \& Sigona, N. (2018). Navigating the central mediterranean in a time of 'crisis': Disentangling migration governance and migrant journeys. Sociology, 52(3), 497-515.

National Crime Agency. (2015). National referral mechanism. Available at: http://www.nationalcrimeag ency.gov.uk/about-us/what-we-do/specialist-capabilities/uk-human-trafficking-centre/national-referralmechanism. Retrieved January 16, 2018.

O’Reilly, K. (2011). Ethnographic methods. Abingdon, Oxon, UK: Routledge.

Oxford English Dictionary. (2019). Corrosion. Available at: https://www.lexico.com/en/definition/corro sion. Retrieved July 30, 2019.

Parliament. UK (2016) Background to the COMPASS contracts. Available at: https://publications.parliament .uk/pa/cm201617/cmselect/cmhaff/637/63703.htm. Retrieved December 11, 2017.

Perraudin, F. (2017) UK asylum seekers living in squalid unsafe slum conditions. The Guardian, 27 October. Available at: https://www.theguardian.com/uk-news/2017/oct/27/uk-asylum-seekers-living-insqualid-unsafe-slum-conditions. Retrieved July 30, 2019.

Pickering, S. (2010). Women, borders and violence: Current issues in asylum, forced migration, and trafficking. New York: Springer.

Safety 4 Sisters. (2016). Migrant women's rights to safety. Manchester: Safety 4 Sisters.

Serco. (2016). Extension of COMPASS contract for UK asylum seeker support services. Available at: https ://www.serco.com/news/media-releases/2016/extension-of-compass-contract-for-uk-asylum-seeke r-support-services. Retrieved December 11, 2017.

Silverman, S., \& Griffith, M. (2018) Immigration detention in the UK. Migration Observatory, 29 May. Available at: https://migrationobservatory.ox.ac.uk/resources/briefings/immigration-detention-in-theuk/. Retrieved May 6, 2019.

Sisters Uncut. (2016). Migrant women and domestic violence, 14 September. Available at: http://www.siste rsuncut.org/2016/09/14/no-sister-is-illegal-migrant-women-and-domestic-violence/. Retreived December 12, 2017.

Snider, J., Hill, R. P., \& Martin, D. (2003). Corporate social responsibility in the 21st century: A view from the world's most successful firms. Journal of Business Ethics, 48(2), 175-187.

Stanko, E. (1990). Everyday violence: How women and men experience sexual and physical danger. London: HarperCollins Ltd.

Tombs, S. (2016). State-corporate crime and harm. In K. Corteen, S. Morley, P. Taylor, and J. Turner (Eds.) A companion to crime, harm and victimisation, companions in criminology and criminal justice (pp. 224-225). Bristol: Policy Press.

UK Visas and Immigration. (2014). Working in the UK while an asylum case is considered, 21 February. Available at: https://www.gov.uk/government/publications/working-whilst-an-asylum-claim-is-consi dered/working-in-the-uk-whilst-an-asylum-case-is-considered. Retrieved December 11, 2017.

United Nations High Commissioner for Refugees. (1951, 1967). Convention and protocol relating to the status of refugees (Geneva Convention). Available at: http://www.unhcr.org/3b66c2aa10.html. Retreived October 20, 2018.

van Houtum, H., \& van Naerssen, T. (2002). Bordering, ordering and othering. Tijdschrift voor Economische en Sociale Geografie, 93(2), 125-136.

Walby, S., \& Towers, J. (2018). Untangling the concept of coercive control: Theorizing domestic violent crime. Criminology and Criminal Justice, 18(1), 7-29.

Weber, L., \& Pickering, S. (2011). Globalisation and borders: Death at the global frontier. Basingstoke, Hampshire, UK: Palgrave Macmillan.

Webber, F. (2012). Borderline justice: The fight for refugee and migrant rights. London: Pluto Press.

Webber, F. (2016). The UK Government's inversion of accountability. Open Democracy. Available at: https ://www.opendemocracy.net/en/shine-a-light/uk-government-s-inversion-of-accountability/. Retrieved July $31,2019$.

Westmarland, N. (2015). Violence against Women: Criminological perspectives on men's violences. Abingdon, Oxon, UK: Routledge.

Whyte, Z. (2011). Enter the myopticon: Uncertain surveillance in the danish asylum system. Anthropology Today, 27(3), 18-21.

Women's Aid. (2015). What is domestic abuse? Available at: https://www.womensaid.org.uk/informatio n-support/what-is-domestic-abuse/. Retrieved November 20, 2018.

Women's Refugee Commission. (2016). Falling through the cracks: Refugee women and girls in Germany and Sweden. New York: Women's Refugee Commission.

Yuval-Davis, N., Wemyss, G., \& Cassidy, K. (2019). Bordering. Cambridge: Polity Press.

Publisher's Note Springer Nature remains neutral with regard to jurisdictional claims in published maps and institutional affiliations. 